\title{
Tingkat konsumsi zat besi (Fe), seng (Zn) dan status gizi serta hubungannya dengan prestasi belajar anak sekolah dasar
}

\author{
Luh Putu Prema Wadhani ${ }^{1}$, Ida Bagus Agung Yogeswara ${ }^{1}$
}

\begin{abstract}
Background: The main problem faced by Indonesia especially in the education field is the achievement of learning in children is still low in Elementary School. Several factor that influence the learning achievement in children are internal factors, external factors and the learning methods. Nutritional status, sufticient iron $(\mathrm{Fe})$ and zinc $(\mathrm{Zn})$ intake is one of the important indicators to improve the growth and development of brain in children.

Objective :The purpose of this study to determine the correlation between level of iron and zinc consumption and nutritional status with children' learning achievement in Elementary School no. 1 Buduk and Elementary School no. 2 Abianbase.

Methods : design of this study was used an Observational Analytics with Cross Sectional Design which has been implemented in April-May 2017 with Simple Random Sampling Technique in the $5^{\text {th }}$ grade students (57 samples).

Result : The result of this study showed that most of the iron $(\mathrm{Fe})$ and zinc $(\mathrm{Zn})$ consumption in medium category that is $64,9 \%$ and $42,1 \%$, while the nutritional status in normal category that is $64,9 \%$ and the learning achievement includes in good category that is $84,2 \%$. The learning achievement related to iron $(\mathrm{Fe})$ and nutritional status $(p=0,000)$ and not associated with the level of zinc $(\mathrm{Zn})$ consumption $(p=0,447)$.

Conclusion : The study showed a correlation between the level of iron $(\mathrm{Fe})$ consumption and nutritional status with learning achievement and there is no correlation between the level of zinc ( $\mathrm{Zn})$ consumption.
\end{abstract}

Keywords: iron, zinc, nutritional status, learning achievement

\begin{abstract}
ABSTRAK
Latar belakang : Permasalahan utama yang dihadapi Indonesia khususnya dalam bidang pendidikan saat ini yaitu masih rendahnya prestasi belajar pada anak sekolah dasar. Beberapa faktor yang dapat mempengaruhi prestasi belajar anak yaitu berupa faktor internal, faktor eksternal dan pendekatan belajar. Status gizi, asupan zat besi (Fe) dan seng (Zn) yang baik merupakan salah satu indikator yang sangat penting dalam membantu proses pertumbuhan dan perkembangan otak anak

Tujuan penelitian : untuk mengetahui hubungan tingkat konsumsi zat besi $(\mathrm{Fe})$, seng $(\mathrm{Zn})$ dan status gizi dengan prestasi belajar anak di SDN No.1 Buduk dan SDN No.2 Abianbase

Metode : Desain penelitian ini adalah penelitian Observationalanalitik yang besifat Cross sectional yang dilakukan pada bulan April-Mei 2017 dengan teknik pengambilan sampel menggunakan simple random sampling, pada anak kelas V (57 sampel). Data tingkat konsumsi zat besi $(\mathrm{Fe})$ dan seng $(\mathrm{Zn})$ dikumpulkan dengan menggunakan form food recall $3 x 24$ jam, sedangkan status gizi dengan menggunakan IMT/U. Teknik analisa data menggunakan uji korelasi rank spearman.

Hasil penelitian : Sebagian besar tingkat konsumsi zat besi $(\mathrm{Fe})$ dan seng ( $\mathrm{Zn})$ termasuk dalam kategori sedang yaitu 64,9\% dan 42,1\%, sedangkan status gizi termasuk dalam kategori normal yaitu 64,9\% dan prestasi belajar termasuk dalam kategori baik $84,2 \%$. Prestasi belajar berhubungan dengan zat besi $(f e)$ dan status gizi $(p=0,000)$ dan tidak berhubungan dengan tingkat konsumsi seng $(\mathrm{Zn})$ yaitu $(p=0,447)$.

Simpulan : Terdapat hubungan antara tingkat konsumsi zat besi (Fe) dan status gizi dengan prestasi belajar dan tidak adanya hubungan tingkat konsumsi seng (Zn) dengan prestasi belajar.
\end{abstract}

Kata kunci : zat besi, seng, status gizi, prestasi belajar

\section{PENDAHULUAN}

Permasalahan utama yang dihadapi Indonesia khususnya dalam bidang pendidikan saat ini yaitu masih rendahnya prestasi belajar pada anak sekolah dasar. ${ }^{1}$ Pencapaian prestasi belajar anak sekolah dasar khususnya kelas IV di Indonesia pada tahun 2015 menduduki peringkat 45 dari 48 negara di dunia yang mengikuti evaluasi di bidang sains, sedangkan pada

1. Program Studi Ilmu Gizi, Fakultas Kesehatan, Sain, dan Teknologi, Universitas Dhyana Pura. Jln. Raya Padang Luwih, Tegaljaya, Dalung, Badung-Bali. (Email korespondensi: ian_prema@yahoo.com) hasil evaluasi matematika menduduki peringkat 45 dari 50 negara di dunia. Keadaan ini membuktikan bahwa prestasi belajar anak khususnya sekolah dasar di Indonesia masih dalam kategori yang rendah.

Beberapa faktor yang dapat mempengaruhi prestasi belajar pada anak yaitu berupa faktor internal (faktor dari dalam diri), faktor eksternal (faktor dari luar) dan pendekatan belajar. Faktor internal terdiri dari faktor fisiologis seperti status gizi dan konsumsi zat gizi, dan juga faktor psikologis seperti tingkat kecerdasan/intelegensi, sikap, bakat, minat dan motivasi anak yang dapat mempengaruhi prestasi belajar. ${ }^{2}$ Status gizi yang baik merupakan indikator yang sangat penting dalam membantu proses 
pertumbuhan dan perkembangan khususnya bagi perkembangan otak anak. ${ }^{3}$ Presentase status gizi anak pada tahun 2013 dengan keadaan kurus dan sangat kurus di Indonesia sebesar 11,2\%, dan dengan keadaan gemuk dan sangat gemuk sebesar $18,8 \%$, sedangkan status gizi anak khusunya di Bali dengan keadaan kurus dan sangat kurus sebesar 8,0\% dan dengan keadaan gemuk dan sangat gemuk sebesar $20 \% .{ }^{4}$ Namun, secara dunia prevalensi status gizi anak dengan keadaan stunting sebesar $24,5 \%$, wasting $7,7 \%$, dengan berat badan kurang $15 \%$ dan kelebihan berat bedan $6,3 \%$.

Dalam beberapa penelitian yang dilakukan pada anak sekolah dasar diketahui bahwa status gizi merupakan salah satu faktor yang dapat mempengaruhi prestasi belajar anak sekolah dasar. Pada penelitian yang dilakukan di Kota Padangpanjang diketahui bahwa terdapat status gizi anak yang mengalami stunting dan wasting memiliki prestasi belajardibawah rata rata yaitu sebesar $30,8 \%$, sedangkan dari hasil penelitian yang dilakukan di Kota Padang diketahui bahwa salah satu faktor yang berperan penting dalam peningkatan prestasi belajar pada anak sekolah dasar yaitu status gizi. ${ }^{5,6}$

Status gizi yang baik terjadi apabila tubuh memperoleh cukup zat gizi, baik zat gizi makro (makronutrient)maupun (mikronutrient)yang akan digunakan secara efisien sehingga memungkinkan membantu dalam pertumbuhan fisik, serta perkembangan otak anak. Pemenuhan kebutuhan zat gizi khususnya zat gizi mikro (mikronutrient) yang optimal pada anak-anak dapat membantu dalam masa pertumbuhan dan perkembangan otak anak. ${ }^{7,8}$ Salah satu zat gizi mikro (mikronutrient) yang berperan dalam perkembangan otak sehingga membantu dalam meningkatkan prestasi belajar anak diantaranya yaitu zat besi $(\mathrm{Fe})$ dan seng $(\mathrm{Zn})$.

Masalah defisiensi zat besi dan seng di Indonesia masih dalam kategori yang cukup tinggi dan menjadi salah satu permasalahan yang terjadi pada anak dengan persentase defisiensi zat besi $(\mathrm{Fe})$ yaitu sebesar 50\% dan defisiensi seng (Zn) sebesar $17 \% .{ }^{7}$ Dilihat dari tingkat konsumsi diketahui bahwa sebesar $79,1 \%$ anak dengan konsumsi zat besi yang kurang dan $94,5 \%$ anak dengan konsumsi seng yang kurang di Kota Semarang. ${ }^{9}$ Defisiensi zat besi $(\mathrm{Fe})$ dapat berdampak pada terjadinya anemia gizi besi dan dapat berpengaruh negatif terhadap fungsi otak sehingga mengakibatkan prestasi belajar anak menurun, ${ }^{10}$ sedangkan jika terjadi defisiensi seng (Zn)dapat berdampak pada terjadinya gangguan pertumbuhan dan kematangan seksual. ${ }^{11}$ Zat besi $(\mathrm{Fe})$ dan seng (Zn) merupakan salah satu mikronutrien yang berfungsi dalam perkembangan otak terutama pada fungsi sistem penghantar syaraf (Neurotransmiter) sehingga berperan dalam peningkatan kecerdasan otak dan kemampuan belajar pada anak. ${ }^{8}$ Beberapa hasil penelitian menunjukkan bahwa terjadi peningkatan yang nyata pada memori dan konsentrasi anak dalam belajar serta kecerdasan otak anak atau IQ setelah diberikan suplemen zat besi dan seng. ${ }^{12,13}$

Dalam penelitian sebelumnya, belum pernah dilakukan penelitian mengenai tingkat konsumsi zat besi $(\mathrm{Fe})$ dan seng $(\mathrm{Zn})$ dengan menggunakan metode foodrecall pada anak usia sekolah dasar yang memilki status gizi yang bervariasi dan dihubungkan dengan prestasi belajar,sehingga dalam penelitian ini dilakukan penentuan asupan zat besi (Fe), seng $(\mathrm{Zn})$ dengan menggunakan metode food recall agar memperoleh gambaran nyata asupan zat besi $(\mathrm{Fe})$ dan seng $(\mathrm{Zn})$ dalam sehari, status gizi dan prestasi belajar anak di SDN 1 Buduk dan SDN 2 Abianbase. Kemudian dianalisis hubungan tingkat konsumsi zat besi $(\mathrm{Fe})$, seng $(\mathrm{Zn})$ dan status gizi dengan prestasi belajar anak. Harapan yang ingin dicapai dalam penelitian ini yaitu agar orangtua dapat lebih memperhatikan pemenuhan gizi khususnya pada pemenuhan zat besi dan seng anak-anak usia sekolah dasar dalam meningkatkan kecerdasan otak anak. Tujuan dari penelitian ini yaitu untuk mengetahui hubungan tingkat konsumsi zat besi $(\mathrm{Fe})$, seng $(\mathrm{Zn})$ dan status gizi dengan prestasi belajar anak di SDN No.1 Buduk dan SDN No.2 Abianbase.

\section{BAHAN DAN METODE}

Desain penelitian ini adalah penelitian Observationalanalitikyang besifat Cross sectional yang dilakukan pada bulan April-Mei 2017 dan dilakukan di SDN No.1 Buduk dan SDN No.2 Abianbase, Kabupaten Badung-Bali. Populasi dalam penelitian ini yaitu anak sekolah dasar kelas V di SDN No.1 Buduk dan SDN No.2 Abianbase sebanyak 107 orang. Teknik pengambilan sampel menggunakan simple random sampling dan diperoleh sampel sebanyak 57 orang.

Data identitas sampel diperoleh dengan melakukan wawancara menggunakan form identitas sampel yang berisi inisial, jenis kelamin, usia, berat badan dan tinggi badan sampel. Data tingkat konsumsi zat besi (Fe) dan seng ( $\mathrm{Zn}$ ) diperoleh dengan melakukan wawancara menggunakan form food recall $3 \times 24$ jam. Pengumpulan data status gizi dilakukan dengan cara mengukur tinggi badan sampel dengan menggunakan mirotoa (microtoise) dan berat badan sampel dengan menggunakan timbangan injak pada ketelitian 0,1. Penentuan status gizi sampel dilakukan berdasarkan Indeks Massa Tubuh menurut Umur (IMT/U) yang mengacu pada Keputusan Menteri Kesehatan Republik Indonesia tentang standar antropometri penilaian status gizi anak tahun 2010. Data prestasi belajar anak diperoleh dengan mencatat data hasil ulangan semester sampel yaitu pada 5 (lima) mata pelajaran yaitu matematika, IPA, IPS, Bahasan 
Indonesia dan Pendidikan Kewarganegaraan. Data dianalisis dengan menggunakan uji korelasi rank spermandilakukan untuk mengetahui hubungan antara variabel.

\section{HASIL}

\section{Karakteristik Sampel}

Karakteristik sampel dalam penelitian ini meliputi usia dan jenis kelamin sampel. Sampel yang diteliti sebanyak 57 orang anak dengan rentang usia 1011 tahun. Adapun karakteristik dalam penelitian ini dapat dilihat pada tabel 1 berikut :

Tabel 1. Karakteristik sampel berdasarkan jenis kelamin dan usia

\begin{tabular}{cccc}
\hline \multicolumn{2}{c}{ Kategori } & Jumlah & Persentase (\%) \\
\hline \multirow{2}{*}{ Jenis Kelamin } & Laki-laki & 20 & 35,1 \\
\multirow{2}{*}{ Usia } & Perempuan & 37 & 64,9 \\
& 11 Tahun & 52 & 91,2 \\
& 10 Tahun & 5 & 8,8 \\
\hline
\end{tabular}

Berdasarkan hasil penelitian diketahui bahwa sebagian besar sampel berjenis kelamin perempuan sebanyak 37 orang $(64,9 \%)$ sedangkan laki-laki sebanyak 20 orang $(35,1 \%)$. Namun dilihat dari usia diperoleh sebagian besar sampel berusia 11 tahun sebanyak 52 orang $(91,2 \%)$ sedangkan 10 tahun sebanyak 5 orang $(8,8 \%)$.

\section{Tingkat Konsumsi Zat Besi (Fe) dan Seng (Zn)}

Berdasarkan hasil analisis rata-rata konsumsi yang diperoleh dengan menggunakan form food recall $3 \times 24$ jam diketahui bahwa rata-rata konsumsi zat besi $(\mathrm{Fe})$ dan seng $(\mathrm{Zn})$ yaitu sebesar $16,98 \mathrm{mg} /$ hari dan $12,52 \mathrm{mg} / \mathrm{hari}$. Data tingkat konsumsi zat besi $(\mathrm{Fe})$ sampel diperoleh dengan membandingkan asupan zat besi $(\mathrm{Fe})$ dan angka kecukupan zat besi $(\mathrm{Fe})$ yang diajurkan (AKG) 2013 yang memperhatikan jenis kelamin dan usia sampel. Adapun rata-rata tingkat konsumsi zat besi $(\mathrm{Fe})$ sampel disajikan pada tabel 2 berikut:

Tabel 2. Distribusi tingkat konsumsi zat besi (Fe) dan seng (Zn)

\begin{tabular}{ccccc}
\hline Kategori & \multicolumn{2}{c}{ Zat besi (Fe) } & \multicolumn{2}{c}{ Seng (Zn) } \\
\cline { 2 - 5 } $\begin{array}{c}\text { tingkat } \\
\text { konsumsi }\end{array}$ & $\mathrm{n}$ & $\%$ & $\mathrm{n}$ & $\%$ \\
\hline baik & 16 & 28,1 & 21 & 36,8 \\
sedang & 37 & 64,9 & 24 & 42,1 \\
kurang & 4 & 7,0 & 12 & 21,1 \\
\hline
\end{tabular}

Berdasarkan tabel diatas diketahui bahwa sebagian besartingkat konsumsi zat besi $(\mathrm{Fe})$ dan seng (Zn) sampel termasuk dalam kategori sedang yaitu sebanyak 37 orang $(64,9 \%)$ dan 24 orang $(42,1 \%)$. Dari hasil wawancara yang dilakukan diperoleh data bahwa bahan makanan yang sering dikonsumsi dengan kandungan zat besi $(\mathrm{Fe})$ dan seng $(\mathrm{Zn})$ yang tinggi yaitu berupa hati ayam, daging ayam, telur, ikan, udang, tahu, tempe, bayam, susu, roti, dan jagung, selain itu makanan pokok yang sering dikonsumsi oleh sampel yaitu nasi.

\section{Status Gizi}

Adapun hasil perolehan status gizi sampel disajikan pada tabel 3 berikut :

Tabel 3.Distribusi Status gizi

\begin{tabular}{ccc}
\hline Kategori & Jumlah & Persentase (\%) \\
\hline Kurus & 4 & 7,0 \\
Normal & 37 & 64,9 \\
Gemuk & 3 & 5,3 \\
Obesitas & 13 & 22,8 \\
\hline
\end{tabular}

Berdasarkan tabel 3 diketahui bahwa sebagan besar status gizi sampel termasuk dalam kategori normal yaitu 37 orang $(64,9 \%)$, sedangkan status gizi sampel dengan kategori kurus sebanyak 4 orang $(7,0 \%)$, gemuk sebanyak 3 orang $(5,3 \%)$, dan obesitas sebanyak 13 orang $(22,8 \%)$.

\section{Prestasi Balajar}

Berdasarkan hasil penelitian diperoleh bahwa rata-rata hasil ulangan semester pada mata pelajaran matematika, IPA (Ilmu Pengetahuan Alam), IPS (Ilmu Pengetahuan Sosial), Bahasa Indonesia, dan PKN (Pendidikan Kewarganegaraan) secara berurutan yaitu 75.21, 79.26, 78.19, 81.33, dan 80.14. Prestasi belajar sampel dalam penelitian ini diperoleh dari hasil ulangan semester seluruh mata pelajaran tersebut yang kemudian seluruh nilai dijumlahkan dan dirata-ratakan serta dikategorikan dalam kategori yang telah ditentukan. Adapun prestasi belajar sampel dapat dilihat pada tabel berikut : 
Tabel 4.Distribusi prestasi belajar

\begin{tabular}{ccc}
\hline Kategori & Jumlah & $\begin{array}{c}\text { Persentase } \\
(\boldsymbol{\%})\end{array}$ \\
\hline Sangat Baik & 5 & 8,8 \\
Baik & 48 & 84,2 \\
Cukup & 4 & 7,0 \\
\hline
\end{tabular}

Berdasarkan Tabel 4 diketahui bahwa sebagian besar prestasi belajar sampel termasuk dalam kategori baik yaitu sebanyak 48 orang $(84,2 \%)$, sedangkan prestasi belajar dengan kategori sangat baik sebanyak 5 orang $(8,8 \%)$ dan kategori cukup sebanyak 4 orang $(7,0 \%)$.

\section{Hubungan Tingkat Konsumsi Zat Besi (Fe) dengan Prestasi Belajar}

Berdasarkan hasil uji korelasi Spearman antara variabel tingkat konsumsi zat besi (Fe) dengan prestasi belajar anak di SDN No.1 Buduk dan SDN No. 2 Abianbase diperoleh hasil bahwa $\mathrm{p}=0,000(\mathrm{p}<0,05)$ sehingga $\mathrm{H}_{\circ}$ ditolak yang berarti terdapat hubungan antara variabel tingkat konsumsi zat besi $(\mathrm{Fe})$ dengan prestasi belajar anak dengan kekuatan korelasi yang kuat yaitu 0,581 .

\section{Hubungan Tingkat Konsumsi Seng (Zn) dengan Prestasi Belajar}

Berdasarkan hasil uji korelasi Spearman antara variabel tingkat konsumsi zat besi $(\mathrm{Fe})$ dengan prestasi belajar anak di SDN No.1 Buduk dan SDN No. 2 Abianbase diperoleh hasil bahwa $\mathrm{p}=0,447(\mathrm{p}>0,05)$ sehingga $\mathrm{H}_{\mathrm{o}}$ diterima yang berarti tidak terdapat hubungan antara variabel tingkat konsumsi seng $(\mathrm{Zn})$ dengan prestasi belajar anak dengan kekuatan korelasi yang kurang berarti yaitu 0,103 .

\section{Hubungan status gizi dengan prestasi belajar}

Berdasarkan hasil uji korelasi Spearman antara variabel status gizi dengan prestasi belajar anak di SDN No.1 Buduk dan SDN No. 2 Abianbase diperoleh hasil bahwa $\mathrm{p}=0,000(\mathrm{p}<0,05)$ sehingga $\mathrm{H}_{\mathrm{o}}$ ditolak yang berarti terdapat hubungan yang signifikan antara variabel status gizi dengan prestasi belajar anak serta kekuatan korelasi yang negatif dalam kategori yang kuat yaitu $-5,19$.

\section{PEMBAHASAN}

Pemenuhan kebutuhan zat gizi khususnya pada pemenuhan zat gizi mikro (mikronutrient) pada usia sekolah sangatlah penting untuk dilakukan karena pemenuhan zat gizi tersebut dapat mempengaruhi pertumbuhan dan perkembangan fisik serta otak anak. Salah satu zat gizi mikro (mikronutrient) yang perperan penting bagi perkembangan otak yaitu zat besi dan seng ${ }^{14} \cdot{ }^{15}$ Hasil penelitian ini sejalan dengan hasil penelitianyang dilakukan di Kecamatan Palu yang memperoleh bahwa sebagian besar tingkat konsumsi zat besi $(\mathrm{Fe})$ dan seng ( $\mathrm{Zn})$ pada anak sekolah dasar usia 10-12 tahun termasuk dalam kategori yang cukup yaitu sebanyak 48 orang $(72,72 \%)$ Namun penelitian ini bertolak belakang dengan hasil penelitian yanng dilakukan di pesisir Semarang yang memperoleh bahwa sebanyak $70 \%$ anak sekolah dasar yang berada di daerah pesisir Semarang beresiko asupan seng yang tidak cukup. Tingginya prevalensi ketidakcukupan asupan zat besi $(\mathrm{Fe})$ dan seng $(\mathrm{Zn})$ disebabkan oleh jumlah asupan bahan makanan yang mengandung seng yang rendah pada daerah pesisir semarang tersebut ${ }^{17}$.

Faktor- faktor yang dapat berpengaruh terhadap pemilihan makanan anak usia sekolah yaitu adanya pengaruh orangtua, pengetahuan gizi yang ada baik orangtua maupun pengasuh anak, interaksi orangtua dan anak, dan jumlah makanan yang dikonsumsi serta ketersediaan pangan yang ada pada lingkungan ${ }^{17}$. Namun, terdapat beberapa faktor lainnya yang dapat mempengaruhi kebiasaan makan pada anak-anak sekolah dasar yaitu adanya teman sebaya, lingkungan baru, pengalaman-pengalaman baru, kegembiraan dan rasa takut disekolah yang akan menyebabkan anak-anak akan menyimpang dari kebiasaan waktu makan sehingga asupan zat gizi yang diperoleh tidak pada setiap anak menjadi berbeda-beda dan menyebabkan tingkat konsumsi setiap anak berbeda-beda ${ }^{14}$.

Salah satu peranan penting zat besi $(\mathrm{Fe})$ dalam tubuh yaitu sebagai kofaktor yang digunakan untuk mengaktifkan enzim Mono Amin Oksidase (MAO) yang berada pada otak yang berfungsi untuk meningkatkan daya konsetrasi ${ }^{18}$.Defisiensi yang terjadi pada zat besi dapat berpengaruh negatif terhadap fungsi otak, terutama terhadapat fungsi sistem neurotransmiter (pengantar saraf) sehingga akibatnya kepekaan reseptor saraf dopamin berkurang dan akhirnya hilang hingga daya konsentrasi, daya ingat, dan kemampuan belajar terganggu ${ }^{8}$.Penelitian ini sejalan dengan penelitian yang dilakukan pada anak sekolah dasaryang memperoleh bahwa terdapat hubungan yang signifikan antara asupan zat besi $(\mathrm{Fe})$ dengan daya konsetrasi belajar pada anak, sehingga penurunan daya konsetrasi yang terjadi pada anak tersebut akan berdampak pada kurangnya penyerapan informasi pada proses belajar tersebut sehingga berpengaruh terhadap prestasi belajar ${ }^{19}$. Selain itu, hasil penelitian lainnya juga menunjukkan bahwa terdapat hubungan yang signifikan pada pemberian jus yang telah difortifikasi oleh zat besi dengan peningkatan yang nyata pada score tes kemampuan kognitif anak sehingga dapat mempengaruhi perkembangan otak anak serta dapat mempengaruhi prestasi belajar pada anak ${ }^{20}$. 
Sengmerupakan salah satu mikronutrien yang berkaitan dengan protein dan berfungsi sebagai struktur sel otak dan neutransmiter yang terlibat dalam memori otak sehingga dapat berpengaruh terhadap perkembangan kognitif dan prestasi belajar ${ }^{21}$. Kekurangan seng kronis pada anak akan mengganggu sistem syaraf pusat dan fungsi otak sehingga akan berakibat pada prestasi yang diperoleh anak ${ }^{11}$. Hasil penelitian ini sejalan dengan penelitian yang dilakukan di Nepal yang memperoleh bahwa tidak terjadi pengaruh yang bermakna pada pemberian suplementasi seng selama 12-35 bulan terhadap intelektual, eksekutif, fungsi kognitif dan fungsi motorik yang dilakukan pada anak usia 7-9 tahun sehingga hal tersebut tidak berpengaruh jangka panjang terhadap prestasi belajar pada anak ${ }^{22}$. Selain itu penelitian yang dilakukan pada anak usia 24-48 bulan menunjukkan bahwa tidak terdapat pengaruh yang nyata pada pemberian suplemen yang mengandung seng $(\mathrm{Zn})$ pada perkembangan motorik halus maupun kasar pada anak tersebut 23. Namun, pada penelitian lainnya menunjukkan bahwa terdapat hubungan antara asupan seng $(\mathrm{Zn})$ dengan memori jangka pendek pada anak ${ }^{24}$.

Tidak adanya hubungan dalam penelitian ini disebabkan karena adanya faktor lain yang dapat mempengaruhi prestasi belajar anak selain tingkat konsumsi seng $(\mathrm{Zn})$, faktor lain tersebut dapat berupa status gizi, kondisi kesehatan indera, motivasi siswa dan bakat yang telah ada yang dapat mempengaruhi hasil dari belajar anak yaitu prestasi belajar anak. Namun, faktor lain yang dapat mempengaruhi perkembangan kognitif anak sehingga dapat mempengaruhi prestasi belajar yaitu faktor konsumsi vitamin A, pendidikan ibu, pekerjaan ibu, usia ibu, dan lingkungan sosial seperti teman dan guru yang dapat meningkatkan motivasi anak dalam belajar ${ }^{21,25}$.

Gizi merupakan salah satu faktor penting yang akan menentukan tingkat kesehatan fisik maupun mental anak-anak khususnya anak pada usia sekolah dasar. Status gizi yang normal tercapai apabila kebutuhan optimal dalam tubuh terpenuhi. Upaya yang dilakukan untuk meningkatkan derajat kesehatan yang optimal pada anak usia sekolah yaitu dengan peningkatan status gizi masyarakat khusunya pada anak usia sekolah ${ }^{26}$. Status gizi yang baik dan optimal terjadi apabila tubuh memperoleh asupan zat gizi yang cukup yang akan digunakan secara efisien sehingga memungkinkan pertumbuhan fisik, perkembangan otak, kemampuan kerja, dan keadaan kesehatan yang berada pada tingkat yang optimal. Tubuh akan mengalami gizi kurang ketika kekurangan salah satu atau lebih zat gizi yang esensial dan sebaliknya apabila pada keadaan status gizi yang $\operatorname{lebih}^{27}$. Salah satu kelompok yang rawan terhadap masalah gizi kurang, gizi baik maupun gizi lebih merupakan kelompok anak usia sekolah. Kekurangan zat gizi yang berdampak pada status gizi pada masa sekolah akan mengakibatkan kondisi fisik anak menjadi lemah sehingga anak menjadi mudah sakit, lemah dan konsentrasi berkurang serta berdampak pada terjadinya penurunan dari hasil belajar di sekolah ${ }^{15}$.

Keadaan fisik yaitu status gizi yang kurang pada anak usia sekolah dapat mengakibatkan tejadinya kerugian pada kecerdasan otak, perkembangan psikomotorik, keterampilan motorik halus dan integrasi neurosensori, selain itu juga anak dapat mengalami gangguan pada belajar dan keterlambatan dalam menyelesaikan sekolah sebagai akibat dari kondisi yang kurang sehat serta status gizi yang kurang ${ }^{28}$.Salah satu faktor penting yang berpengaruh terhadap perkembangan kognitif maupun motorik anak yang akan berpengaruh terhadap keberhasilan anak dalam belajar di sekolah adalah status gizi ${ }^{29}$. Beberapa penelitian menujukkan terdapat hubungan antara status gizi dengan prestasi belajar serta perkembangan kognitif, selain itu status gizi yang kurang pada anak akan berpengaruh terhadap daya konsetrasi belajar, pemahaman verbal, persepsi visual dan daya ingat. anak usia sekolah ${ }^{26,30,31}$.

\section{SIMPULAN}

Berdasarkan hasil penelitian disimpulkan bahwa tingkat konsumsi zat besi (Fe), dan status gizi berhubungan dengan prestasi belajar anak sekolah dasar sedangkan tingkat konsumsi seng ( $\mathrm{Zn}$ ) tidak berhubungan dengan prestasi belajar anak.

\section{DAFTAR PUSTAKA}

1. Rahmawati. Hasil TIMSS 2015 (Trend in International Mathematics and Science Study) Diagnosa hasil untuk perbaikan mutu dan peningkatan capaian.2015. [Accessed 18 Januari 2016].Available at: Puspendik.kemdikbud.go.id

2. Syah M. 2015. Psikologi Belajar. Jakarta: PT RajaGrafindo. 2015

3. Badan Penelitian dan Pengembangan Kesehatan Kemterian Kesehatan RI, Riset Kesehatan Dasar. Riskesdas;2013.

4. World Health Organization. World Health Statistics 2015. World Health Organization;2015

5. Sa'adah H, Herman RB, Sastri S. Hubungan status gizi dengan prestasi belajar siswa sekolah dasar negeri 01 Guguk Malitang Kota Padangpanjang. Jurnal Kesehatan Andalas. 2014;3(3):460-465.

6. Oktavia S, Yulius Y.Faktor faktor yang berhubungan dengan prestasi belajar pada siswa Sekolah Dasar Negeri 47 Korong Gandang Kec.Kuranji Kota Padang tahun 2014. Jurnal IPTEKS Terapan. 2015;8(3):74-82. 
7. Hidayati L, Hadi H, Kumara A. Kekurangan Energi Dan Zat Gizi Merupakan Faktor Risiko Kejadian Stunted Pada Anak Usia 1-3 Tahun Yang Tinggal Di Wilayah Kumuh Perkotaan Surakarta. Jurnal Kesehatan. 2010;4(1):89-104.

8. Almatrsier, S. Prinsip Dasar Ilmu Gizi. Jakarta: PT. Gramedia Pustaka Utama. 2010

9. Ardiaria M, Nuryanto. Hubungan Status Gizi dan Asupan Besi dan Seng terhadap Fungsi Motorik Anak Usia 2-5 tahun. Journal Nutrition Health. 2014;2(2)

10. Adriari M, Wirjatmadi B. Peranan gizi dalam siklus kehidupan. Jakarta: Kencana Perdana Media Group. 2012

11. Cakrawati D, Handayani N. Bahan Pangan,Gizi dan Kesehatan. Cetakan. Bandung : Penerbit Alfabeta.2012.

12. Chaundhary J, et al. A Study of iron and zinc deficiency on short term memory in children \& effect of their supplementation. Asian Journal of Biomedical and Pharmacceutical Sciences. 2015;5(42):12-15.

13. Carpenter KK. et al. Magnetic susceptibility of brain iron is associated with childhood spatial IQ. Journal of NeuroImage. 2016;132:167-174.

14. Anzarkusuma S, Mulyani Y, Jus'at I, Angkasa D. Status Gizi Berdasarkan Pola Makan Anak Sekolah Dasar di Kecamatan Rajeng Tanggerang. Indonesian Journal Of Human Nutrition 2014;1(2):135-148.

15. Sholeha S, Sakung J, Kusumawati E. Hubungan Asupan Zat gizi makro dan zat gizi mikro dengan status gizi anak sekolah usia 10-12 tahun di SDN 5 Palu Kecamatan Palu. Jurnal Promotif. 2014;4(1):12-21.

16. Pramono A, Panunggal B, AnggraeniN, Rahfiludin Z. 2016. Asupan seng, kadar serum seng, dan stunting pada anak sekolah di pesisir semarang. Jurnal Gizi Pangan. 2016;2(1):19-26.

17. Almatsier S., Soetardjo S., Soekarti M. Gizi Seimbang Dalam Daur Kehidupan. Jakarta: PT. Gramedia. 2011

18. Hayati W, et al. Pola konsumsi pangan dan asupan energi dan zat gizi anak stunting dan tidak stunting 0-23 bulan. Jurnal Gizi dan Pangan. 2012;7(2):7380.

19. Wardoyo A, Mahmudiono T. Hubungan Makan Pagi Dan Tingkat Konsumsi Zat Gizi Dengan Daya Konsentrasi Siswa Sekolah Dasar. Jurnal Media Gizi Indonesia. 2013;9(1):49-53.

20. Agdepp A, Magsadia R. Multi-micronutrient Fortified Beverage Delivered through the SchoolBased System Improved Iron Status and Test Scores of Children. Journal of Food Science and Engineering. 2015;5(5):112-121.
21. Setyaningrum R., Triyanti, Indrawani Y. Pembelajaran di Pendidikan Anak Usia Dini dengan perkembangan kognitif pada anak. Jurnal Kesehatan Masyarakat Nasional. 2014;8(6):243249

22. Kold ME, Khatry S, Katz J, Schafer BA. Preschool Micronutrient Supplementation Effects on Intellectual and Motor Function in School-aged Nepalese Children. Arch pediatr adolesc med. 2012;166(5):404-410.

23. Nugroho AN, Susanto HM, Kartasurya. Pengaruh mikronutrien taburia terhadap perkembangan motorik anak usia 24-48 bulan yang stunting (Studi di Tanjungkarang Barat Kabupaten, Bandar Lampung). Jurnal Gizi Indonesia.2014;3(1):5259.

24. Setianingsih, Dasuki DI. Zinc deficiency and school-age children's. J Med Sci.2014;46(3):117124.

25. Latief A. Pengaruh lingkungan sekolah terhadap hasil belajar pendidikan kewarganegaraan pada peserta didik di smk negeri paku kecamatan binuang kabupaten polewali mandar. Jurnal Pepatuzdu. 2014;7(1):13-26.

26. Legi N. Hubungan Status Gizi dengan Prestasi belajar siswa Sekolah Dasar Negeri Malalayang Kecematan Malalayang. Jurnal Gizi Indo. 2012;4(1):321-326.

27. Indrati R, Gardjito M. Pendidikan Konsumsi Pangan Aspek Pengolahan dan Keamanan. Jakarta: Kencanan Prenata Media Group. 2014.

28. Arfines P, Puspitasari D. Hubungan Stunting dengan Prestasi Belajar Anak Sekolah Dasar di Daerah Kumuh, Kotamadya Jakarta Pusat. Buletin Penelitian Kesehatan. 2017;45(1):45-52.

29. Solihin M, Anwar F, Sukandar D. Kaitan status gizi, perkembangan kognitif, dan perkembangan motorik pada anak usia prasekolah. Jurnal Penelitian gizi dan makanan 2013;36(1):62-72.

30. Triastuti J., et al. Pengaruh status gizi dan tonsilitis kronik terhadap prestasi belajar pada siswa sekolah dasar. Jurnal Biomedika. 2015;7(1):2734.

31. Sudargo, T. et al. Hubungan Antara Status Gizi, Anemia, Status Infeksi, Dan Asupan Zat Gizi Dengan Fungsi Kognitif Pada Anak Sekolah Dasar Di Daerah Endemik Gaki. Gizi Indon. 2012;35(2):126-136. 